Anthropos: Jurnal Antropologi Sosial dan Budaya (Journal of Social and Cultural Anthropology)

7 (1) (2021): 88-97, DOI: 10.24114 /antro.v7i1.24643

Anthropos: Jurnal Antropologi Sosial dan Budaya (Journal of Social and Cultural Anthropology)

Available online http://jurnal.unimed.ac.id/2012/index.php/anthropos

\title{
Pewarisan Nilai-Nilai Tradisi Budaya Suku Anak Dalam Air Hitam, Sarolangun, Provinsi Jambi
}

\section{Inheritance of the Cultural Values Suku Anak Dalam Air Hitam, Sarolangun, Provinsi Jambi}

\author{
Priazki Hajri \& Junaidi Indrawadi* \\ Program Magister Pendidikan Pancasila dan Kewarganegaraan, Fakultas Ilmu Sosial, \\ Universitas Negeri Padang, Indonesia
}

Diterima: 28 April 2021; Direview: 03 Mei 2021; Disetujui: 08 Mei 2021

Abstrak

Artikel ini bertujuan untuk mendeskripsikan bagaimana pewarisan nilai-nilai tradisi budaya Suku Anak Dalam Air Hitam, Sarolangun, Jambi. Penelitian dilakukan dengan pendekatan kualitatif. Data-data dikumpulkan melalui observasi, wawancara, dokumentasi. Data dianalisis dengan teknik analisis data yaitu reduksi data, penyajian data, dan penarikan kesimpulan. Pengujian keabsahan data dengan trianggulasi sumber. Hasil penelitian menemukan bahwa Pewarisan kearifan lokal Suku Anak Dalam Air Hitam Sarongun Jambi dilakukan dengan tatap muka langsung, keterlibatan generasi muda (anak) dalam budaya, dan aturan adat istiadat. Nilai yang diwariskan yaitu nilai individu, sosial dan nilai kecintaan terhadap tanah air.

Kata Kunci: Pewarisan; Nilai;, Tradisi Budaya.

\begin{abstract}
This article aims to describe how the inheritance of the cultural traditions values of the Suku Anak Dalam Air Hitam, Sarolangun, Jambi. The research was conducted with a qualitative approach. Data collected through observation, interviews, documentation. Data were analyzed using data analysis techniques, namely data reduction, data presentation, and drawing conclusions. Testing the validity of the data by triangulation of sources. The results of the study found that the inheritance of cultural traditions values Suku Anak Dalam Air Hitam, Sarongun Jambi was carried out face-to-face, the involvement of the younger generation (children) in culture, and customary rules. The values inherited are individual, social and love values for the country.

Keywords: Inheritance; Value; Cultural Traditions.
\end{abstract}

How to Cite: Hajri, P., Indrawadi, J., (2021). Pewarisan Nilai-Nilai Tradisi Budaya Suku Anak Dalam Air Hitam, Sarolangun, Jambi. Anthropos: Jurnal Antropologi Sosial dan Budaya Uournal of Social and Cultural Anthropology), 7 (1): 88-97.

*Corresponding author: ISSN 2549-1660 (Print)

E-mail: Hajri716@gmail.com ISSN 2550-1305 (Online) 


\section{PENDAHULUAN}

Suku Anak Dalam merupakan salah satu suku yang berada dari Provinsi Jambi. Suku Anak Dalam populasinya sebanyak 3198 jiwa yang tersebar dalam lingkup provinsi Jambi (Asra et al., 2018). Penyebaran suku anak dalam terdapat di kabupatan Sarolangun, Merangin, Batang Hari, Tanjab Barat, Tebo Dan Bungo dengan berlatar belakang etnik Melayu (Mailinar \& Nurdin, 2013).

Dari Enam (6) kabupaten penyebaranya, Suku Anak Dalam paling banyak berada di Sarolangun dengan jumlah populasi 1095 jiwa, kemudian Merangin dengan 858, tebo 823, Bungo 286, Batang Hari 79 dan Tanjab Barat 57 orang (Sinaga \& Rustaman, 2015).

Suku Anak Dalam memiliki Kepercayaan yang dianutnya yakni Animisme, ataupun percaya kepada Makhluk Halus ataupun roh-roh leluhur mereka (Kuswanto, 2016), (Mailinar \& Nurdin, 2013). Hutan merupakan tempat tinggal yang nyaman bagi mereka, sehingga mereka sangat menjaga dan melestarikan hutan tersebut (Sinaga \& Rustaman, 2015). Sumber makanan mereka berasal dari hasil buruan, seperti Biawak, Babi hutan, Ular, Kijang, Rusa dan binatang lainnya yang ada di dalam hutan.

Suku Anak Dalam masih mempertahankan warisan nenek moyangnya, berupa cara mencari makan dengan berburu, pengeolaan obat-obatan dengan tumbuhan serta cara hidup (Kuswanto, 2016). Suku anak dalam memiliki kebiasaan yang unik dengan mempertahankan karakteristiknya sebagai orang rimba dengan memakai lapisan baju sehelai saja sebagai penutup kemaluan, dan dilengkapi dengan atribut gelang dan kalung yang mereka yakini memiliki nilainilai tersendiri (Tarib, 2012).

Suku Anak Dalam sudah banyak mendapatkan perhatian dari pemerintah, dengan diberikannya bantuan seperti pakaian, makanan, dan tempat tinggal yang lebih layak untuk dihuni di tengah- tengah Hutan (Asra et al., 2018). Namun dibalik itu semua mereka tidak memanfaatkan bantuan yang diberikan, mereka tetap berpegang teguh dan yakin terhadap kebiasaan hidup yang seperti mereka jalani (Kuswanto, 2016). Padahal dampak dari bantuan yang diberikan pemerintah akan membuat mereka memiliki kehidupan yang lebih layak.Tidak hanya itu pemerintah selama ini juga telah memberikan bantuan obat-obatan generic namun mereka tetap percaya pada obatobatan yang berasal dari alam (Asra et al., 2018).

Hal ini menunjukkan ada sebuah tradisi pewarisan budaya yang kuat yang membuat Suku Anak Dalam bertahan dengan kehidupan mereka. Dengan kondisi yang seperti ini menarik untuk diulas lebih dalam, bagaimana pewarisan tradisi budaya mereka sehingga mereka tetap teguh terhadap warisan warisan yang di berikan oleh leluhur mereka.

Tidak hanya itu, suku anak dalam juga memiliki warisan nilai nilai yang di dapatkannya dari para leluhurnya, dapat terlihat dimana mereka sangat menjaga lingkungan dan hutan yang dianggap mereka adalah sebagai rumah dan warisan leluhur yang harus mereka hormati dan hargai (Sinaga \& Rustaman, 2015).

Nilai-nilai Tradisi Budaya yang dipegang teguh oleh Suku Anak Dalam yakni 1). Mencari telur atau dilarang kawin dengan anak sendiri, 2). Menikam bumi/ tidak boleh kawin dengan ibu dewek atau ibu sendiri, 3) melebung dalam/ tidak boleh kawin dengan saudara sendiri, 4) mandi pancuran/tidak boleh kawin dengan istri orang (Kuswanto, 2016).

Nilai-nilai karakter juga melekat pada diri Suku Anak Dalam baik itu nilai individual dan nilai sosial, nilai-nilai ini dianut dan juga diwarisi oleh para leluhur mereka dimana nilai-nilai karakter ini juga tercantum dalam peraturan adat mereka. Adapun nilai-nilai individu dan nilai sosial suku anak dalam yaitu kemanusiaan, 
Kepedulian terhadap lingkungan, dan menjaga keharmonisan.

Pada sisi lain, di samping peran Pemerintah seperti yang telah diungkapkan di atas, sebenarnya banyak yang membuat Suku Anak Dalam bisa melepaskan kepercayaan dan tradisi mereka, salah satunya banyak masyarakat pendatang disekitar kehidupan mereka. Padahal hal ini disinyalir akan membuat mereka sedikit banyaknya terpengaruh. Namun kenyataanya mereka tetap pada kepercayaan dan tradisi yang mereka pilih.

Tujuan penelitian ini adalah dapat menggambarkan bagaimana pewarisan nilai-nilai tradisi budaya Suku Anak Dalam Air Hitam, Sarolangun, Jambi sehingga Suku Anak Dalam tetap dapat mempertahankan kehidupanya. Serta apa nilai-nilai yang diwariskan oleh pada Suku Anak Dalam Air HItam, Sarolangun, Jambi.

Implikasi dari penelitian ini akan memberikan sumbangan warna tersendiri di bidang penelitian karena implikasinya pada dunia penelitian akan sangat bermanfaat bagi penambahan kapasitas dan wawasan baru bagi siapa saja. Terutama mengungkap nilai-nilai tradisi budaya apa saja yang terkandung pada kehidupan Suku Anak Dalam. Selain itu penelitian ini akan sangat bermanfaat bagi penambahan ilmu pengetahuan di bidang karakter dan nilai-nilai, karena memberikan sumbangan yang besar serta teori yang relevan bagi dunia pendidikan.

Penelitian-penelitian tentang Suku Anak Dalam sudah pernah dilakukan. Penelitian Takidin tentang nilai-nilai kearifan lokal Orang Rimba, hasilnya penelitianya menemukan implementasi nilai-nilai kearifan lokal Orang Rimba terlihat pada konsistenti mereka dalam menjaga hutan dimana hal ini mereka menyebutnya dengan istilah Bompongan, dan Orang Rimba juga merawat berbagai macam bunga untuk di gunakan dalam tradisi Basale (Takiddin, 2014).

Penelitian Dwi Kurniawan dan Rista Ardilla tentang Basale sebagai kearifan lokal Suku Anak Dalam di desa Nyogan kecamatan Mestong kabupaten Muaro Jambi, Penelitian ini bertujuan untuk mendeskripsikan sebuah kearifan lokal Suku Anak Dalam yaitu Besale di mana tradisi ini masih tetap eksist sampai saat sekarang dan terus di warisi secara turun temurun (Kurniawan \& Aldilla, 2018).

Penelitian Asridawati, Parawati dan Yulianis penelitian ini bertujuan untuk melihat salah satu pewarisan kearifan lokal Suku Anak Dalam berupa etnofarmasi yakni teknik pengobatan dengan memanfaatkan sumber dari alam. Hasil dari penelitian ini adalah salah satu kearifan lokal berupa pewarisan pengobatan dari nenek moyang masih di jalankan berupa cara-cara pengobatan, bahan-bahan pengobatan serta sumbersumber yang di sediakan oleh alam dan hutan (Asridawati et al., 2020).

\section{METODE PENELITIAN}

Jenis penelitian yang digunakan adalah penelitian kualitatif dengan pendekatan deskriptif kualitatif. Pendekatan deskriptif kualitatif merupakan penelitian yang memiliki tujuan dalam mengetahui dan memahami fenomena-fenomena yang dialami (Moleong, 2014). Dengan demikian maka melalui pendekatan deskriptif kualitatif penulis dapat menggambarkan tentang pewarisan nilai-nilai tradisi budaya Suku Anak Dalam Air Hitam, Sarolangun, Jambi.

Dalam pengumpulan data, peneliti melakukan Observasi, wawancara dan dokumentasi (Sugiyono, 2018). Pengujian keabsahan data dengan Teknik triangulasi. Teknik triangulasi merupakan pengecekan kebenaran data yang dilakukan dengan membandingkan data yang didapat dari sumber-sumber yang lain yaitu dengan membandingkan data wawancara dengan observasi dan dokumentasi.

Teknik analisis data dilakukan dengan cara deskriptif kualitatif analisa. Deskriptif kualitatif analisa yaitu proses analisa yang berusaha memberikan 
gambaran terperinci berdasarkan kenyataan yang penulis temui di lapangan. Analisis data adalah usaha-usaha dalam menyusun data yang diperoleh dari hasil wawancara, observasi, dan dokumentasi dengan mengelompokan kedalam kategori-kategori yang sejalan dengan tujuan dari penelitian. Analisis data dilakukan dengan reduksi data, penyajian data, dan Penarikan kesimpulan (Sugiyono, 2018)

\section{HASIL DAN PEMBAHASAN \\ Gambaran Umum Suku Anak Dalam Air Hitam Sarolangun}

Sejarah Suku Anak Dalam masih penuh misteri, bahkan hingga kini belum ada yang bisa meyakinkan dan memastikan asal usul Dari Suku Anak Dalam. Hanya cerita dari mulut ke mulut para keturunan yang bisa menampilkan sedikit sejarah kelompok sosial ini. Asal Suku Anak Dalam terdapat dua versi yaitu. Pertama, orang perkampungan yang pergi lari kehutan. Kedua, Suku Anak Dalam berasal dari Minangkabau, tepatnya dari Pagaruyung, Sumatera Barat (Sinaga \& Rustaman, 2015). Suku Anak Dalam berasal dari Pagaruyung didukung oleh bahasa, garis keturunan dan sistem larangan perkawinan suku anak dalam sama dengan bahasa, garis keturunan matriliniar dan larangan-larangan pernikahan dalam sistem garis keturunan Minangkabau.

Suku Anak Dalam hidup dengan berkelompok-kelompok, tapi eksistensi kelompok tidak dibatasi oleh wilayah tempat tinggal tertentu. Suku Anak Dalam bebas dan merdeka untuk tinggal bersama dengan kelompok lain. Namun mereka suku anak dalam tidak dapat dengan mudah berganti-ganti kelompok atau pemimpinya.

Susunan organisasi sosial pada masyarakat Suku Anak Dalam terdiri dari Tumenggung, Wakil Tumenggung, Depati, Menti, Mangku, Anak Dalam, Debalang Batin, Tengganas/Tengganai. Posisi yang tertinggi ditempati oleh Tumenggung, namun walaupun Tumenggung memiliki kekuasaan yang tinggi namun Tumenggung tidak dapat semena-mena dalam kehidupan bermasyarakat bahkan untuk putusan Tumenggung dalam adatpun dapat dibatalkan oleh Tengganas. Dengan adanya struktur dan pembagian tugas tersebut terlihat Suku Anak Dalam menjalankan kehidupan bermasyarakat dengan demokratis (Sinaga \& Rustaman, 2015)

Masyarakat Suku Anak Dalam aktifitas kehidupanya dilakukan didalam hutan, sehinga memiliki cara sendiri dalam mengelola sumberdaya alam. Hutan bagi Suku Anak Dalam merupakan harta yang tidak ternilai harganya karena tempat mereka hidup, berkembang biak, sumber kebutuhan pokok, serta tempat dilakukanya upacar -upacara adat istiadat dan ritua-ritual dalam beragam (Tarib, 2012; Sinaga \& Rustaman, 2015).

Makanan pokok suku anak dalam adalah ubi kayu, padi ladang, ubi jalar, pisang, dan tebu dengan begitu maka mata pencaharian Suku Anak Dalam adalah bertani atau berladang. Tempat bertani atau berladang bagi mereka dibagi menjadi dua tempat yaitu sesap dan belukar. Sesap tempat bertani atau berladang untuk kebutuhan pokok, sementara, belukar tempat bertani atau berladang buahbuahan. Selain itu, Suku Anak Dalam juga bertani dan berladang untuk mengahasilkan alat dan bahan yang digunakan untuk rumah sebagai tempat tinggalnya, obat, dan perlengkapa untuk berburu makanan.

Suku Anak Dalam Air Hitam Sarolangun memiliki kepercayaan terhadap Dewa. Dewa akan memberikan kebaikan jika menjalankan aturan dan kehidupan dengan baik, namun jika dilakukan kebalikanya maka akan mendatangkan petaka.

Dewa bagi Suku Anak Dalam Saro Langun dipanggil dengan Bahelo (Mailinar \& Nurdin, 2013). Bahelo atau dewa bagi 
suku anak dalam adalah pemberi aturanaturan kehidupan Suku Anak Dalam. Suku Anak Dalam harus patuh terhadap aturan tersebut jika ingin mendapatkan kebajikan. Namun ketika Suku Anak Dalam melanggar aturan-aturan yang ditetapkan oleh Dewa maka Suku Anak Dalam Air Hitam Sarolangun mempercayai akan mengalami petaka.

\section{Bentuk Pewarisan Nilai-Nilai Tradisi Budaya Suku Anak Dalam}

Bentuk pewarisan nilai-nilai tradisi budaya Suku Anak Dalam Air Hitam Sarongun dilakukan dalam bentuk tatap muka langsung, keterlibatan generasi muda (anak) dalam budaya, dan aturan adat istiadat. Pertama, tatap muka langsung. Tatap muka langsung yang dilakukan dalam pewarisan budaya dalam Suku Anak Dalam Air Hitam Sarolangun adalah dengan interaksi langsung antara generasi tua dengan generasi muda Suku Anak Dalam. terjadi tatap muka langsung antara orang tua atau generasi tua suku anak dalam dengan anak-anak atau generasi muda suku anak dalam.

Yang diajarkan para generasi tua ini adalah menyangkut tradisi-tradisi, aturanaturan adat dan kepercayaan-kepercayaan yang mereka anut. Tidak sedikit juga para generasi tua memberikan cerita-cerita tentang nenek moyang mereka yang terdengar banyak mengandung nilai-nilai.

Agen pewarisan nilai-nilai kearifan lokal Suku Anak Dalam Air Hitam Sarolangun dilakukan oleh Orang Tua, Tumenggung dan Tetua-Tetua yang memahami tentang nilai-nilai budaya dan kepercayaan suku anak dalam. Agen pewarisan kearifan lokal budaya menyampaikan budaya-budaya melalui cerita-cerita legenda, mistis, kepercayaan aturan sopan satun, dan bentuk-bentuk budaya suku anak dalam.

Pewarisan nilai-nilai kearifan lokal dengan metode tatap muka yang dilakukan oleh Suku Anak Dalam tidak dilakukan secara sengaja dan sistematis. Artinya kegiatan tatap muka yang dilakukan oleh suku anak dalam tidak dengan jadwal yang ditetapkan. Bahkan pewarisan nilai-nilai kearifan lokal yang mereka lakukan tidak dengan sistem guru dan murid. Mereka melakukan tatap muka dalam pewarisan nilai-nilai dilakukan secara santai, dan tidak kaku.

Kedua, keterlibatan didalam tradisi. Suku Anak Dalam Air Hitam Sarolangun melakukan pewarisan nilai-nilai kearifan lokal dengan cara melibatkan anak-anak (generasi muda) dalam tradisi-tradisi Suku Anak Dalam. Tradisi-tradisi suku anak terdiri dari tradisi melangun, basale, temalam dan tradisi menanam bersama.

Tradisi melangun dalam Suku Anak Dalam menyangkut upacara dalam kematian. Tradisi melangun adalah tradsi perpindahan tempat tinggal yang dilakukan oleh seluruh anggota keluarga suku anak dalam karena adanya anggota keluarga mereka yang berpindahan dan pencarian tempat baru harus dilakukan karena keyakinan dan kepercayaan suku anak dalam bahwa tanah atau permukiman tempat tinggal akan menjadi sial jika ada yang meninggal ditempat itu.

Tradisi melangun bertujuan agar suku anak dalam tidak berlarut-larut dalam kesedihan karena meninggalnya salah satu keluarga mereka. Jenazah anggota keluarga yang meninggal dalam tradisi Melangun ditutup dengan kain dari mata kaki hingga menutupi kepala. Jenazah atau orang yang sudah meninggal dalam tradisi Melangun ini ditutup dengan kain dari kepala sampai mata kaki. Kain yang digunakan tidak ditentukan yang terpenting kepala sampai mata kaki jenazah dapat tertutup.

Selain itu jenazah Suku Anak Dalam tidak dikuburkan atau dibakar tapi diletakan pada pondok yang dibuat tidak jauh dari pemukiman yang akan ditinggalkan oleh suku anak dalam yang masih hidup. Jenazah yang meninggal itu diangkat oleh tiga orang menuju pondok tempat jenazah itu ditinggalkan yang 
berjarak lebih dari 5 KM ke arah hutan dari tempat tinggal jenaza. Pondok tempat diletakan jenazah dibuat dengan batang kayu kecil sebagai alas dan daun-daun kering sebagai atapnya.

Keterlibatan generasi muda dalam tradisi Melangun ini adalah mengangkat jenazah ketempat jenazah itu ditinggalkan. Selain mengangkat jenazah, anak-anak muda Suku Anak Dalam pada tradisi Melangun ini adalah mencari tempat bermukim yang baru serta membawa perlengkapan dan peralatan ketempat pindah.

Tradisi Basale merupakan upacara keagaaman atau kepercayaan Suku Anak Dalam dengan tujuan meminta keselamatan dan terhindar dari mara bahaya. Tradisi Basale ini dipimpin oleh tokoh yang memiliki kemampuan berkomunikasi dengan dunia ghaib.

Dapat dikatakan bahwa tradisi basale ini merupakan sesuatu upacara yang sakral dilakukan oleh Suku Anak Dalam Air Hitam Sarolangun. Upacara Basale ini dilakukan pada malam hari. Tradisi Basale ini dilakukan malam hari dan tidak diboleh diketahui oleh orang luar (masyarakat terang).

Doa yang diminta dalam acara Basale ini harus dimulai dengan permintaan pengampunan dan penyesalan karena telah membuat dewa marah. Tradisi Basale merupakan ritual penyembahan untuk meminta kesembuhan penyakit dan keselamatan yang dilakukan oleh suku anak dalam. Ritual dalam tradisi Basale dilakukan jika ada anggota keluarga suku anak dalam sakit. Dalam ritual ini selain meminta kesehatan dan kesembuhan juga meminta pengampuan kepada Dewa disertai dengan penyesalan dari keluarga yang sakit karena telah melakukan kesalahan sehingga dewa marah dan memeberikan penyakit. Tradisi basale menggunakan kemeyan dan jenis-jenis bunga yang terdiri dari 100 macam. Selain itu juga menggunakan bunyi-bunyian dan tarian-tarian.
Tradisi Temalam adalah tradisi berburu makanan yang dilakukan oleh suku anak dalam dalam usaha pemenuhan kebutuhanya. Tradisi ini dilakukan pada malam hari sampai pagi yang dilakukan secara berkelompok-kelompok. Dalam kelompok terdiri dari anak-anak muda yang dipimpin oleh satu atau dua orang tua. Binatang yang diburu dalam tradisi Temalam adalah Kambing Hutan, Rusa Dan Kijang.

Ketiga, Aturan adat istiadat. Aturan adat istiadat Suku Anak Dalam merupakan salah satu cara Suku Anak Dalam mempertahankan kebudayaanya. Aturanaturan adat istiadat Suku Anak Dalam berpedoman kepada Saloko.

Bentuk aturan adat istiadat Suku Anak Dalam yang terdapat dalam Saloko Suku Anak Dalam Air Hitam Sarolangun yaitu Pantang dunia terang, dilarang berduaan, Aturan dalam kehidupan sosial, Aturan adat istiadat dalam hukum waris.

Pantang dunia terang dalam aturan adat istiadat Suku Anak Dalam adalah aturan untuk membatasi kehidupan mereka dengan dunia luar dari mereka. Dalam suku anak dalam, perempuan dan laki-laki Suku Anak Dalam dilarang berdua-duaan. Dalam kehidupan sosial, suku anak dalam mengedepankan adab sopan santun yang terkenal dengan pepatah aturanya bejenjang naik betaggo turun, tidak buruk di pakai, tidak habis dimakan.

Harta warisan dalam aturan adat istiadat suku anak dalam diserahkan kepada istri dan anak. Jika suami istri yang meninggal maka harta warisan itu diberikan kepada anak mereka.

Dengan demikian maka pewarisan kearifan lokal dalam Suku Anak Dalam Air Hitam Sarolangun ini digolongkan kepada bentuk pewarisan nilai yang dilakukan secara tradisional. Bentuk pewarisan budaya masyarakat tradisional ditandai dengan penyampain mulut ke mulut dan praktek langsung (Darusman \& Mumu, 2019). Masyarakat tradisonal mewariskan 
kearifan lokal dengan cara membawa langsung anaknya untuk turut serta dalam melaksanakan kebudayaan tersebut. pewarisan budaya dilakukan dengan tatap muka langsung dengan menurunkan dan menceritakan cerita legenda, mitos, dan dongeng olehorang tua bertatap muka langsung dengan anak-anaknya (Kodiran, 2004).

Kemudian Sumarto menyatakan bahwa kearifan lokal biasanya diterima sebagai tradisi, serta pewarisanya dilimpahkan dari angkatan tua kepada angkatan lebih muda. Proses pewarisan tersebut diterapkan melalui pembelajaran nilai dan keterampilan (Sumarto, 2019).

Hal ini juga terjadi pada Suku Anak Dalam Air Hitam Sarolangun yang mewarisi kearifan lokalnya dengan keterlibatan generasi muda dan anak-anak dalam setiap tradisi. Tradisi-tradisi suku anak dalam itu meliputi tradisi Melangun, tradisi Bahela, tradisi Temalam dan tradisi Menanam Bersama.

Pada tradasi melangun dimana generasi tua melibatkan generasi muda pada penyelanggara jenazah degan mengangkat jenazah ketempat peristrahatan terakhir jenazah serta dalam tradisi melangun generasi tua juga melibatkan generasi muda dalam mencari tempat pemukiman baru.

Pada tradisi Basale, generasi tua melibatakan generasi muda mencari alat dan pelengkapan yang dibutuhkan untuk tradisi ritual keagama basale seperti mencari kemayan dan 100 jenis bunga. Selain itu generasi muda juga ikut ritual dan berdoa bersama yang dipimpin oleh tetua yang alim. Dalam tradisi Temalam, generasi muda juga ikut dalam berburu binatang pada malam hari, yang ditangkap itu seperti kijang, rusa dan kambing hutan.

Spoza dan Fieldman dalam Darusman dan Mumu menyatakan bahwa sistem pewarisan atau transformasi kearifan lokal merupakan langkah dalam mempertahankan ide, gagasan, atau keterampilan dalam sebuah kebudayaan umumnya dilakukan melalui tradisi kesenian dan khususnya melalui proses belajar (Darusman \& Mumu, 2019).

Lebih lanjut Spoza mengungkapkan Terdapat dua jenis sistem pewarisan nilainilai yakni Vertical Transmission dan Horizontal Transmission (Darusman \& Mumu, 2019). Dalam hal ini Suku Anak Dalam Air Hitam telah memenuhi unsur transformasi budaya dalam mempertahankan ide, gagasan dan keterampilan budaya melalui kesenian (tradisi) dan belajar.

Namun dari dua jenis pewarisan yang dikemukakan oleh Spoza yaitu Vertical Transmission dan Horizontal Transmission. Suku Anak Dalam Air Hitam hanya melakukan Vertical Transmission. Vertical Transmission (Pewarisan tegak) ialah sistem pewarisan yang berlangsung melalui metode keturunan yang diturunkan dari masa ke masa secara antar generasi. Penurunan tersebut terdiri dari penurunan ciri-ciri budaya dari orang tua kepada anak-cucu. Dalam pewarisan tegak, orang tua mewariskan nilai, keterampilan, keyakinan, motif budaya, dan sebagainya kepada anak-cucu mereka.

Sedangkan untuk Horizontal Transmission belum bisa dilakukan dan dipenuhi oleh Suku Anak Dalam karena Horizontal Transmission adalah sistem pewarisan yang terjadi melalui lembagalembaga pendidikan seperti sekolahsekolah. Sementara itu Suku Anak Dalam belum mengenal dan memiliki lembagalembaga pendidikan seperti Sekolah. Bahkan untuk dalam metode pendidikanpun Suku Anak Dalam sangat jauh dari bentuk metode pendidikan yang dilakukan secara sengaja, sadar dan sistematis dimana Suku Anak Dalam tidak memeliki materi yang jelas dan tersusun, waktu dan tempat tidak dijadwalkan secara tetap dan berkelanjutan.

Upaya-upaya bentuk pendidikan yang tersusun dan sitematis dalam sebuah lembaga pendidikan ini bahkan ditolak oleh suku anak dalam karena dipandang 
sebagai budaya masyarakat terang. Hal ini ditentang oleh aturan adat istiadat suku anak dalam.

Menurut Piotr dalam Kodiran, masyarakat mewariskan kebiasaan dan keyakinan dengan beberapa cara yaitu, Pertama, Tradisi dan adat istiadat (nilai, norma yang mengatur perilaku dan hubungan antar individu dalam kelompok). Kedua, Nasehat dari para leluhur. Ketiga, Peranan orang yang dituakan (pemimpin kelompok yang memiliki kemampuan lebih dalam menaklukkan alam) dalam masyarakat. Keempat, Membuat suatu tanda kepada semua anggota kelompok masyarakat berupa lukisan atau alat bantu hidup serta bangunan tugu atau makam (Kodiran, 2004).

Melalui empat bentuk pewarisan yang dikemukan oleh Piotr terdapat kesamaan dengan yang dilakukan oleh Suku Anak Dalam Air Hitam Sarolangun. Pertama, mengenai tradisi dan adat istiadat ini merupakan kewajiban dan keharusan untuk dilakukan oleh setiap generasi Suku Anak Dalam. Jika tidak dilakukan maka akan keluar dari Suku Anak Dalam. Upaya-upaya ini dilakukan oleh Suku Anak Dalam untuk menjaga kebudayaanya.

Kedua, mengenai Nasehat-nasehat. Nasehat-nasehat ini dipertahankan dengan jalan mempertahantakan ingatan kolektif anggota masyarakat dan kemudian disampaikan secara lisan turun temurun dari satu generasi ke generasi selanjutnya.

Ketiga, Peranan orang yang dituakan (pemimpin kelompok yang memiliki kemampuan lebih dalam menaklukkan alam) dalam masyarakat. Pemimpin kelompok menyampaikan secaralisan sebuah ajaran yang harus ditaati oleh anggota kelompoknya. Dalam Suku Anak Dalam Air Hitam dinamakan Tumenggung. Untuk saat ini suku anak dalam dipimpin oleh Bapak Tumenggung Ngadap.

Keempat, Membuat suatu tanda kepada semua anggota kelompok masyarakat berupa lukisan atau alat bantu hidup serta bangunan tugu atau makam. Dalam hal ini suku anak dalam membut pondok yang alasnya dari kayu-keyu kecil dan atapanya dari daun-daun kering untuk tempat jenazah.

\section{Nilai-Nilai Yang Diwariskan Dalam Tradisi Budaya Suku Anak Dalam}

Terdapat tiga bentuk nilai yang diwariskan dalam tradisi budaya Suku Anak Dalam Air Hitam Sarolangun, Jambi yaitu nilai individu, nilai sosial dan nilai kebangsaan. Nilai individu terdiri dari nilai semangat kerja dan pantang menyerah, nilai taat terhadap tradisi dan kepercayaan, serta nilai tertutup.

Nilai sosial terdiri dari nilai gotong royong dan sopan santun. Untuk nilai kebangsaan, Suku Anak Dalam lebih kepada kecintaan terhadap tempat tinggalnya serta kecintaan terhadap tradisi dan kebudayaan yang telah diturunkan oleh nenek moyang mereka.

Nilai gotong royong yang terdapat pada Suku Anak Dalam sejalan dengan betuk nilai sosial. Nilai sosial merupakan nilai yang mengandung kebersamaan dan gotong royong sehingga nilai kebersamaan dan gotong royong ini akan bermanfaat positif dalam kehidupan berkelompok.

Selain itu pada dasarnya manusia dan setiap masyarakat memperjuangkn nilai-nilai dasar yang sama, seperti cinta, kebaikan, keindahan, keadilan, persaudaraan, persahabatan, persatuan, perdamaian, dan sebagainya (Suraya et al., 2016). Dengan demikian nilai yang dikemukakan Suraya terdapat juga pada nilai-nilai yang ditemukan pada suku anak dalam air hitam sarolangun yaitu dimana pada nilai-nilai yang hidup pada suku anak dalam mengandung cinta, persaudaraan, dak kebaikan.

Nilai-nilai yang diwariskan oleh Suku Anak Dalam dipandang mulia dan baik oleh Suku Anak Dalam sehingga Suku Anak Dalam selalu berusaha untuk mewariskan nilai-nilai tersebut. Hal ini senada dengan 
yang disampaikan oleh Koentjaraningrat dalam Suraya yang mengatakan nilai budaya terdiri dari konsepsi - konsepsi yang hidup dalam alam fikiran dan pandangan masyarakat mengenai hal - hal yang mereka anggap amat mulia (Suraya et al., 2016). Sehingga sistem nilai yang ada terdapat pada masyarakat dijadikan sebagai orientasi dan pedoman dalam bertindak.

\section{SIMPULAN}

Pewarisan nilai-nilai tradisi budaya Suku Anak Dalam Air Hitam Sarongun Jambi dilakukan dengan tatap muka langsung, keterlibatan generasi muda (anak) dalam budaya, dan aturan adat istiadat. Tatap muka langsung dilakukan dengan interaksi langsung antara generasi tua dengan generasi muda suku anak dalam. Keterlibatan generasi muda (muda) dilakukan dengan mengajak generasi muda suku anak dalam terlibat tradisi Melangun, Basale, Temalam dan tradisi Menanam Bersama. Aturan adat istiadat suku anak yaitu Pantang dunia terang, Dilarang berduaan, Aturan kehidupan sosial, hukum waris. Nilai tradisi budaya yang wariskan suku anak dalam Air Hitam Sarolanhun yaitu nilai individu, nilai sosial dan nilai kebangsaan. Nilai individu terdiri dari nilai semangat kerja dan pantang menyerah, nilai taat terhadap tradisi dan kepercayaan, serta nilai tertutup. Nilai sosial terdiri dari nilai gotong royong dan sopan santun. Untuk nilai kebangsaan, suku anak dalam lebih kepada kecintaan terhadap tempat tinggalnya serta kecintaan terhadap tradisi dan kebudayaan yang telah diturunkan oleh nenek moyang mereka.

\section{DAFTAR PUSTAKA}

Asra, R., Naswir, M., Kalsum, U., \& Lestari, A. P. (2018). Peningkatan Kualitas Pendidikan untuk Anak Suku Anak Dalam di Dusun Selapik, Kabupaten Muaro Jambi. Jurnal Karya Abdi Masyarakat, 2(1), 1-8.

Asridawati, I., Perawati, S., \& Yulianis, Y. (2020). Studi Etnofarmasi pada Suku Anak Dalam
(SAD) di Desa Semambu Kecamatan Sumay Kabupaten Tebo Provinsi Jambi.

Bagit, V. F. (2017). Orientasi nilai budaya di kalangan perempuan terhadap model pakaian di kota manado vini fitriana bagit 13081107015. Holistik, 19, 1-25.

Darusman \& Mumu. (2019). Model Pewarisan Budaya Melalui Pendidikan Informal (Pendidikan Tradisional) Pada Masyarakat Pengrajin Kayu. Wacana Akademika: Majalah Ilmiah Kependidikan, 3 (1), 95-108

Erlinda, P., Montessori, M., Studi, P., \& Sosial, F. I. (2020). JUPIIS : Jurnal Pendidikan Ilmu-ilmu Sosial Pembinaan Nilai-nilai Karakter Kewirausahaan Siswa dalam Membangun Karakter Bangsa Indonesia Development of Student Entrepreneurship Character Values in Building the Character of the Indonesian Nation. 12(2), 344-353.

Ermitati. (2014). "Pengungkapan Budaya Suku Anak Dalam melalui Kosakata Bahasa Kubu." Kandai, 10(2), 153--164.

Kodiran. (2004). Pewarisan Budaya. Humaniora, 16(1), 10-16.

Kurniawan \& Aldilla. (2018). Besale sebagai Kearifan Lokal Suku Anak Dalam di Desa Nyogan Kecamatan Mestong Kabupaten Muaro Jambi, Jambi. Sinergitas Quadruple Helix, 1, 274-287.

Kuswanto, H. (2016). Representasi Budaya Suku Anak Dalam pada Kumpulan Cerita. Riksa Bahasa, 2(1), 48-54.

Mailinar, \& Nurdin, B. (2013). Kehidupan Keagamaan Suku Anak Dalam di Dusun Senami Lii Desa Jebak Kabupaten Batanghari. Kontekstualita, 28(2), 141-157.

Moleong, L. (2014). Metodologi Penelitian Kualitatif. Remaja Rosdakarya.

Sidik, H. (2016). Impresi Orang Rimba: "Melangun" Sebuah Komposisi musik Dalam Interpretasi Perjalanan Orang Rimba. Jurnal Puitika, 12(2), 122-134.

Sinaga, L. Y., \& Rustaman, N. Y. (2015). Nilai-Nilai Kearifan Lokal Suku Anak Dalam Provinsi Jambi terhadap Perladangan di Hutan Taman Nasional Bukit Duabelas sebagai Sumber Belajar Biologi. Seminar Nasional XII Pendidikan Biologi FKIP UNS 2015, 761-766.

Sugiyono. (2018). Metode Penelitian Kualitatif, Kuantitatif, dan R\&d. Bandung : CV. Alfabeta.

Sumarto. (2019). Budaya, Pemahaman dan Penerapannya"Aspek Sistem Religi, Pengetahuan, Sosial, Keseninan dan Teknologi". Jurnal Literasiologi, 1(2), 157.

Suraya, M., Dayati, U., \& Hardika, H. (2016). Pewarisan Nilai-Nilai Budaya Lokal Di Malang Raya (Studi Kaus Paes Manten Style Malangan). Jurnal Pendidikan: Teori, 
Penelitian, Dan Pengembangan, 1(8), 16491658.

Takiddin, T. (2014). Nilai-Nilai Kearifan Budaya Lokal Orang Rimba (Studi pada Suku Minoritas Rimba di Kecamatan Air Hitam Provinsi Jambi). SOSIO DIDAKTIKA: Social
Science Education Journal, 1(2). https://doi.org/10.15408/sd.v1i2.1258

Tarib, T. (2012). Hutan adalah rumah dan sumber penghidupan kami. Kesaksian Tumenggung, sidang per, 1-21. 